\title{
Investigation of Metacognition Level of Secondary School Students in Solving Islamic-based Numerical Literacy
}

\author{
Dewi Rosikhoh ${ }^{1, *}$ Abdussakir Abdussakir ${ }^{2}$ M. I. Mukmin ${ }^{3}$ \\ ${ }^{1,2}$ Postgraduate Program of Mathematics Education, UIN Maulana Malik Ibrahim, Malang, Indonesia \\ ${ }^{3}$ Department of Mathematics Education, UIN Maulana Malik Ibrahim, Malang, Indonesia \\ ${ }^{*}$ Corresponding author. Email: dewirosikhoh@gmail.com
}

\begin{abstract}
The integrated mathematical problem was the application of mathematics to solve problems from various disciplines. This study aimed to determine students' metacognition level in solving integrated mathematics problems. In addition, it can also improve students' numerical literacy. This research was qualitative research with data collection instruments, a one-question problem-solving test, and interviews. Research subjects for interviews were students with the highest score based on the test results. The results showed that students with mathematical abilities in high category at semireflective use and level of reflective use. That happened because subjects used Islamic-integrated knowledge to create problem-solving strategies in their metacognitive activities. Therefore, if students knew Islamic material, they could reach a good metacognition level in solving Islamic-integrated mathematics problems.
\end{abstract}

Keywords: Metacognition level, Secondary school students, Integrated mathematics problems, Problemsolving strategies.

\section{INTRODUCTION}

As a part of complex problems, integrated mathematics problems can be used to solve problems from various disciplines. Integrated mathematics problems involve other disciplines in the process of solving them. The integration can be in the form of integration of mathematics with diverse fields [1-4], integration of mathematics with the culture [5-9], and integration of mathematics with religion [10-12]. Thus, students need to have the ability to solve these integrated problems to face the challenges of the globalization era, which demands complex problem-solving skills [13]. One of the factors that influence success in solving mathematical problems is metacognition [14,15]. Aljaberi declares that there is a significant correlation between metacognitive thinking factors and problemsolving ability [16]. The correlations are procedural knowledge, evaluation, error choosing, and managing knowledge. Metacognitive reflection builds awareness of tasks and strategies, mainly through planning and monitoring, to collect the metacognitive skills needed for problem-solving [17]. Thus, students need to have good metacognitive abilities for the success of solving complex mathematical problems.
Studies on students' metacognition level in solving mathematical problems had been done by many researchers, as reported in previous publications [18-23]. However, such works were generally related to the metacognition level of mathematical ability in high school students $[18,21]$ and secondary school students [20,22-24]. Mahromah's and Siagian et al.'s research showed that the metacognition level of secondary school students with mathematical abilities in the high category reached the highest level of strategic use [20,22]. Previous research stated that the first intermediate students with high mathematical abilities reached the level of reflective use [23].

Furthermore, such previous works examined the metacognition level in solving mathematical problems [18,20-22] and mathematical literacy [23]. Therefore the application of the metacognition level in solving integrated mathematics problems for secondary school students is rarely reported. Additionally, the metacognition level of secondary school students had not yet reached the highest level [20,22]. Thus, it is crucial to conduct research related to the metacognition level of secondary students in solving integrated mathematics problems. It is certainly interesting because integrated 
mathematics problems involve concepts from other disciplines in the problem-solving process.

As a country with the largest Muslim population in the world, Indonesia has its uniqueness in learning. Uniquely, this education is divided into general-based education and Islamic-based education. General-based education at the secondary school level is divided into secondary school and Islamic secondary school. The Islamic-based education at the secondary school level is Madrasah Tsanawiyah. Mathematics is also present in solving problems, especially those related to Islamic integrated mathematics problems. As a Muslim majority population, cases related to Islamic issues often arise, as an example in the distribution of inheritance [25]. Previous studies were generally still in the form of general mathematical problems. Therefore, investigation of the metacognition level of secondary school students in solving Islamic-integrated mathematics problems is essential to research.

\section{METHODS}

This research used an exploratory and descriptive study to investigate the students' metacognition level in solving integrated mathematics problems. Qualitative data analysis in this study used the model proposed by Miles and Huberman, namely data reduction, data presentation, and conclusion [26]. Qualitative data was gained from students' work on a one-question problemsolving test and interview results. The research data in the form of the results of the problem-solving test work and the interviews were summarized and focused on essential things related to the metacognition level. Furthermore, data reduction was carried out based on the results of interviews conducted after the test.

The test was given to 24 students, from secondary school students, Islamic secondary students, and Madrasah Tsanawiyah students. The 24 students had different categories of mathematical ability based on the teacher's recommendations: 6 students with low ability level, 12 students with middle ability level, and 6 students with high ability level. Before being given a problemsolving test, the 24 students conducted a competency test. They did a test to categorize the mathematical abilities of the 24 prospective subjects. The problem-solving test was directed to 24 students who had used the trianglebased learning module on metacognition and integration [11]. The selected subjects were the students with the highest score. The results of the subjects' interviews were converted into transcripts. This research used time triangulation, which set many interviews several times to get valid data. Finally, data reduction was converted to narrative text to produce coherent and evident data. The detail of metacognition level indicators in solving mathematical problems can be found in Table 1 [27].
Table 1. Coding of students' metacognition level indicators in solving mathematical problems

\begin{tabular}{|c|c|c|}
\hline Level & Indicators & Coding \\
\hline $\begin{array}{l}\text { Semi } \\
\text { Reflective } \\
\text { Use }\end{array}$ & $\begin{array}{l}\text { 1. Rethinking past knowledge } \\
\text { that can be used. } \\
\text { 2. Check and thought again of } \\
\text { his work. } \\
\text { 3. Doing reflection does think } \\
\text { during the process of solving, } \\
\text { but is limited to certain parts. } \\
\text { 4. Tend to prove the final result. } \\
\text { 5. Convinced of the correctness } \\
\text { of the answer after checking. }\end{array}$ & $\begin{array}{l}\text { SR4 } \\
\text { SR5 }\end{array}$ \\
\hline $\begin{array}{l}\text { Reflective } \\
\text { Use }\end{array}$ & $\begin{array}{l}\text { 1. Understanding and mastering } \\
\text { mathematical concepts } \\
\text { became the basis of the } \\
\text { problem by realizing that the } \\
\text { concepts learned are helpful } \\
\text { to solve the problem. } \\
\text { 2. Planing and solving strategies } \\
\text { by identifying the problem. } \\
\text { 3. Rethink the plans that have } \\
\text { been made and use different } \\
\text { strategies to improve the } \\
\text { precision of thought. } \\
\text { 4. Always check every step and } \\
\text { revise directly if finding an } \\
\text { error. } \\
\text { 5. Think again about the } \\
\text { methods that have been used } \\
\text { and the results obtained. } \\
\text { 6. Think of another way to solve } \\
\text { the problem. } \\
\text { 7. Rethink about the effective- } \\
\text { ness of the strategies that } \\
\text { have been used. }\end{array}$ & R6 \\
\hline
\end{tabular}

\section{RESULTS AND DISCUSSION}

The instrument used to determine students' metacognition level was a one-question problem-solving test and interview guidelines. Before being used, experts have validated the problem-solving test instrument and interview guide. The subjects did the problem-solving test after they used the module for independent study [11]. Based on the results of the problem-solving test, two subjects got the highest score. Both of them have 
mathematical abilities in the high category. After the test, the researchers used semi-structured interviews to explore some pieces of the information which was not obtained from problem-solving problems. Based on data reduction and triangulation, the results of interview 1 were valid. The following is the process of the subject's

Table 2. Analysis of interview results and works of subject SY in solving integrated mathematics problems

\begin{tabular}{|c|c|}
\hline Interview Results and Works of Subject SY & $\begin{array}{l}\text { Category of } \\
\text { Metacognition Level } \\
\text { Indicator }\end{array}$ \\
\hline 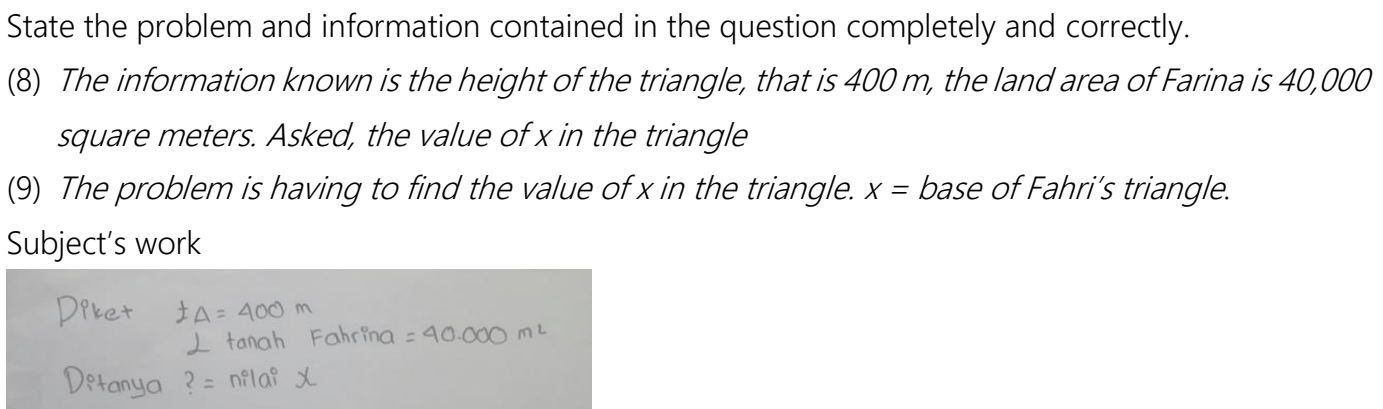 & R1 and SR1 \\
\hline 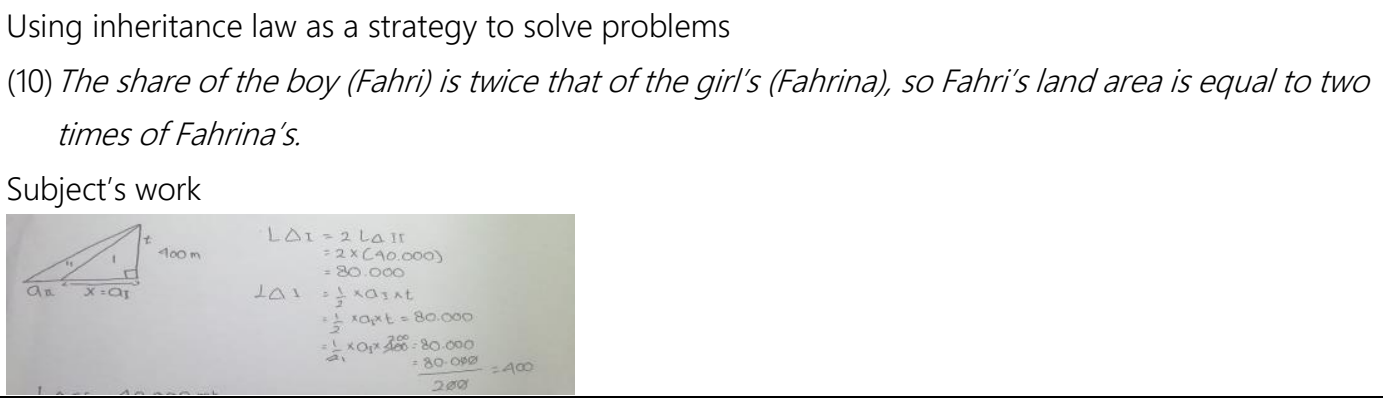 & R2 and SR1 \\
\hline $\begin{array}{l}\text { Checking the results of his work, and correcting when something goes wrong } \\
\text { (11) There was something wrong with my work, so / corrected it. }\end{array}$ & SR2 \\
\hline 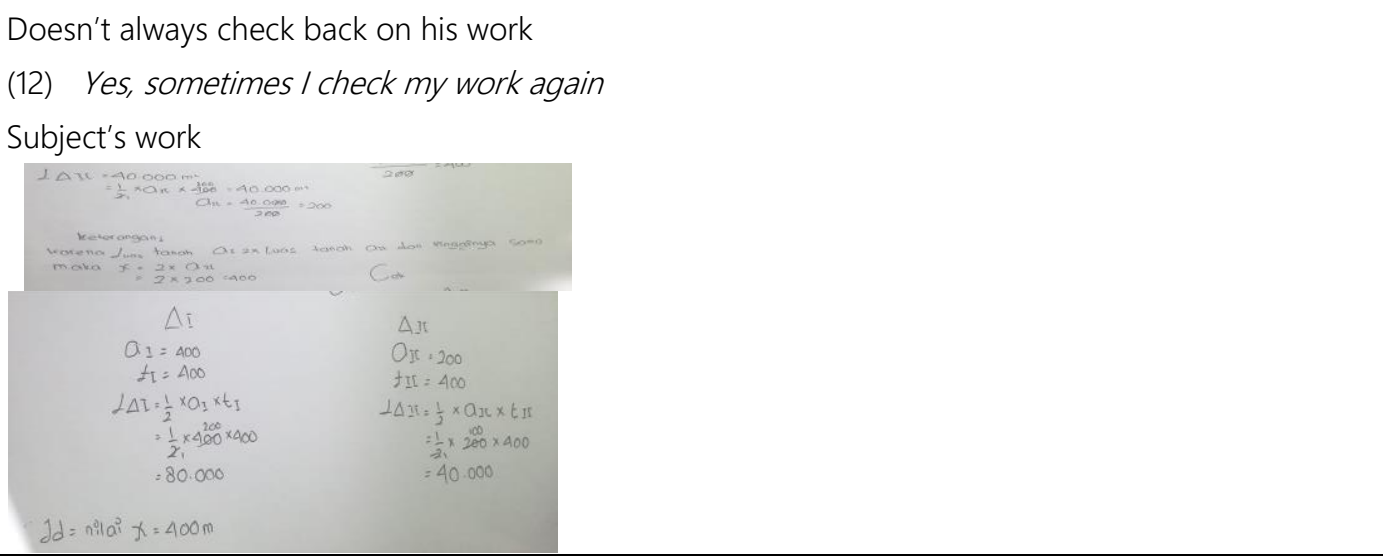 & SR3 \\
\hline $\begin{array}{l}\text { Conduct inspections on processes and final results } \\
\text { (13) I saw the final result, ma'am, if the final result is the same, it means that my calculations are } \\
\text { correct. I also checked this one (pointing to the calculation process), I'm afraid there's a } \\
\text { miscalculation. }\end{array}$ & SR4 \\
\hline $\begin{array}{l}\text { Convinced with the answers obtained because they have used various methods } \\
\text { (14) Sure, because / have checked in various ways. }\end{array}$ & SR5 \\
\hline $\begin{array}{l}\text { Determine the most effective way } \\
\text { (15) The method in which the base of one is equal to twice the base of two because all you have to } \\
\text { do is multiply. }\end{array}$ & R7 \\
\hline
\end{tabular}


metacognition in solving integrated mathematics problems.

Table 3. Analysis of interview results and works of subject ST in solving integrated mathematics problems

\begin{tabular}{|c|c|}
\hline Interview Results and Works of Subject SY & $\begin{array}{l}\text { Category of } \\
\text { Metacognition } \\
\text { Level Indicator }\end{array}$ \\
\hline $\begin{array}{l}\text { State what to ask and what is known in the question completely and correctly } \\
\text { (1) This is ma'am (while pointing to the question text), the length of the side of the land that } \\
\text { is not yet known in Fahri's part is the base of one triangle } \\
\text { (2) It is known that two heirs are Fahri and Fahrina, Fahrina's land area is } 40000 \text { square meters, } \\
\text { and one side of Fahri's land is the height of the triangle equal to } 400 \text { meters. }\end{array}$ & R1 and SR1 \\
\hline $\begin{array}{l}\text { Using inheritance law as a strategy in solving problems } \\
\text { (3) Using inheritance law information, the amount of inheritance for boys is twice that for } \\
\text { girls. Because Fahrina's land area is } 40000 \text { square meters, Fahri's land area should be } 80000 \text { square } \\
\text { meters. } \\
\text { (4) It's in the module. } \\
\text { Subject's work }\end{array}$ & R2 and SR1 \\
\hline $\begin{array}{l}\text { Checking the calculations and methods used and using more than one method } \\
\text { (5) If the area of Fahri's triangle } 1 \text { is calculated, that is, the area of / is equal to half times four } \\
\text { hundred is equal to eighty thousand, now eighty thousand is equal to twice the area of Fahrina's } \\
\text { triangle 2, it means that method } 1 \text { is correct, as is method 2. The large of area } 1=1 / 2 \times 400 \times 400 \\
=80000=2 \times \text { area of triangle 2(Fahrina)..., means method } 1 \text { is correct as well as method } 2 . \\
\text { Subject's work } \\
\qquad \begin{array}{l}\text { (6) } \\
\text { (6) }\end{array}\end{array}$ & R3 \\
\hline (7) So during my work, there are no errors because / always check. & R4 dan SR2 \\
\hline
\end{tabular}




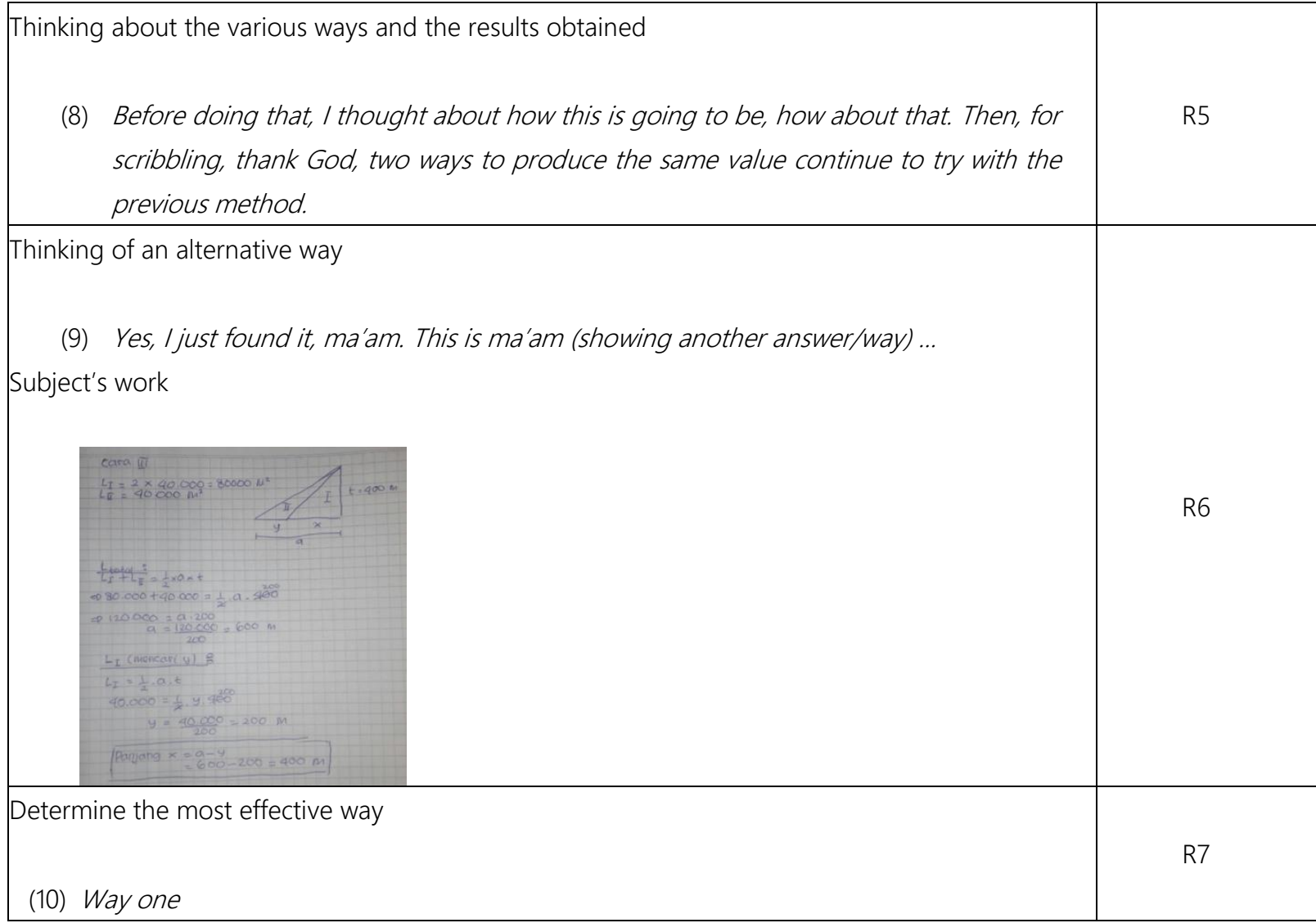

\subsection{Subject SY}

Based on data analysis in Table 2, the subject SY fulfilled the indicators R1, R2, and R7. Subject SY also fulfilled the SR1, SR2, SR3, SR4, and SR5 indicators. Thus, subject SY is categorized as being at the level of semi-reflective use in solving Islamic integrated mathematics problems.

\subsection{Subject $S T$}

Based on data analysis in Table 3, subject ST fulfilled the indicators R1, R2, R3, R4, R5, R6, and R7. Additionally, subject ST also fulfilled the SR1 and SR2 indicators. Thus, subject ST in solving Islamic integrated mathematics problems, categorized as being at the level of reflective use.

Based on the analysis results as shown in Table 2 and Table 3, subject ST and the subject SY were aware of the problem and some information. This result indicates that the two subjects had carried out awareness on metacognition activities [28-30]. The analysis results of subject ST and SY also showed planning activities such as using integrated knowledge, namely inheritance law. Subject ST and SY also carried out monitoring, such as when they stated that they checked the results of their calculations at each completion step. Additionally, subject ST and SY also carried out evaluation activities such as comparing the final results obtained and selecting the most effective method from the methods used. Their actions consisting of three metacognitive skills: planning, monitoring, and evaluation, can help students control their thinking or learning processes [31,32].

The metacognition level of subject ST and SY shows a reflection activity in solving problems. So, two subjects laid the level of reflective use. This is related to the grading of Swartz and Perkins' ranking [24]. The existence of imperfections in reflection activities carried out by subject SY in solving integrated mathematics problems indicates her level of semi-reflective use [27]. Reflection activities carried out by subject SY in this study also differ from previous studies' results. Subject SY reflects during and after solving problems. The previous research stated that students reflect when solving problems at the level of semi-reflective use [21]. Students tend to reflect on the completion steps they have taken. Meanwhile, according to Laurens, at the semireflective use level, students tend to check the truth of the final results [27].

Additionally, there is a different indicator from previous research [18,20-24,27]. It appears in the results of the investigations in Table 2 (3) and Table 3 (3)-(4). Students use the law of inheritance to determine the size of the triangular sides of the inherited land. The student stated that the amount of land inherited by sons is twice as large as that of daughters. Students obtain information about the law of inheritance from the modules they read. It indicates that students use integrated knowledge to create strategies in solving Islamic-integrated 
mathematics problems. This indicator is important because using the right strategy will determine success in solving problems [33]. Furthermore, integrated mathematics problems can instill the seeds of faith, purity, and noble character and provide new challenges for students. This argument is encouraged by Cozza \& Oreshkina, which state that challenging assignments are one of the conditions that make students more reflective and more metacognitive [34]. In addition, non-routine questions are the main thing to solve various problems in the real world $[34,35,36]$.

Another finding in this study is that the metacognition level of the subject in solving Islamic-integrated mathematics problems reached the level of reflective use. This finding aligns with previous research $[23,24]$. In contrast, this result is different from previous research that secondary school students only reach the level of strategic use in solving problems $[20,22]$.

\section{CONCLUSION}

Based on the results and discussion, students' metacognition level in solving Islamic-integrated mathematics problems reaches the level of semireflective use and reflective use. Students achieve this level with mathematical abilities in the high category. The characteristics of the students' metacognition are: 1) affirming what to ask and what is known in the question completely and correctly 2) using inheritance law as a strategy in solving problems 3) checking the calculations and methods used and using more than one method 4) rechecking the results of the work 5) thinking about various ways and the results obtained 6) thinking of another way to solve the problem, and 7) determining the most effective way to solve the problem. There is a difference in checking between subjects at semi-reflective use and a subjects at reflective use. A subject at the level of semireflective use checks during and after solving the problem. While a subject at the level of reflective use checks before, during, and after solving the problem.

\section{AUTHORS' CONTRIBUTIONS}

All authors conceived and designed this study. All authors contributed to the process of revising the manuscript, and in the end, all authors have approved the final version of this manuscript.

\section{REFERENCES}

[1] J. Chauvot, M. M. Lee, Online instruction about integration of science and mathematics with middlegrades teachers: Four years in and aiming for sustainability, Internet High. Educ., vol. 24, 2015, pp. 46-52.

[2] K. Hollebrands, S. Okumuş, Secondary mathematics teachers' instrumental integration in technology-rich geometry classrooms, J. Math. Behav., vol. 49, October 2018, pp. 82-94.
[3] C. F. Loeffler, R. Galimberti, H. de M. Barcelos, A self-regularized Scheme for solving Helmholtz problems using the boundary element direct integration technique with radial basis functions, Eng. Anal. Bound. Elem., vol. 118, May 2020, pp. 11-19.

[4] L. Nutov, Integrating visual arts into the mathematics curriculum: The case of pre-service teachers, Teach. Teach. Educ., vol. 97, 2021, p. 103218.

[5] Y. d'Entremont, Linking Mathematics, Culture and Community, Procedia - Soc. Behav. Sci., vol. 174, no. 1999, 2015, pp. 2818-2824.

[6] S.E. Forsström, Role of teachers in students' mathematics learning processes based on robotics integration, Learn. Cult. Soc. Interact., vol. 21, May 2019, pp. 378-389.

[7] K. Massarwe, I. Verner, D. Bshouty, Ethnomathematics and Multi-Cultural Education: Analysis and Construction of Geometric Ornaments Journal of Mathematics and Culture," J. Chem. Inf. Model., 2013.

[8] I. Verner, K. Massarwe, D. Bshouty, "Development of competencies for teaching geometry through an ethnomathematical approach," J. Math. Behav., vol. 56, no. 1, pp. 1-14, 2019.

[9] T. Turmudi, E. Susanti, D. Rosikhoh, M. Marhayati, Ethnomathematics: Mathematical Concept in the Local Game of Tong Tong Galitong Ji for High School, Particip. Educ. Res., vol. 8, no. 1, 2021, pp. 219-231.

[10] T. Ekawati, B. S. Anggoro, Komarudin, Pengembangan modul pembelajaran matematika pada materi statistika terintegrasi nilai-nilai keislaman, J. Progr. Stud. Pendidik. Mat., vol. 8, no. 1, 2019, pp. 184-192.

[11] D. Rosikhoh, A. Abdussakir, S. Harini, Pengembangan modul pembelajaran segitiga berbasis metakognisi dan integrasi, J. Anal., vol. 7, no. 1,2021 , pp. 99-111.

[12] S. Yuniati, A. Sari, Pengembangan Modul Matematika Terintegrasi Nilai-Nilai Keislaman melalui Pendekatan Realistic Mathematics Education (RME) di Propinsi Riau, J. Anal., vol. 4, no. 1, 2018, pp. 157-165,

[13] D. Rosikhoh, L. Mardhiyatirrahmah, A. Abdussakir, A. Abtokhi, I. Rofiki, Experienced teachers' perceptions: Math-focused STEAM learning, Abjadia, vol. 4, no. 2, 2019, p. 118.

[14] C.M. Aurah, S. Keaikitse, C. Isaacs, H. Fincii, The Role of Metacognition in Everyday Problem Solving Among Primary Students in Kenya, Probl. Educ. 21st Century, vol. 30, 2011, pp. 9-21.

[15] L.L. Chimuma, I.D. Johnson, Assessing Students 
Use of Metacognition during Mathematical Problem Solving Using Smartpens, Educ. Res. Theory Pract., vol. 28, no. January, 2016, pp. 22-36.

[16] N. M. Aljaberi, 'University Students' Learning Styles and Their Ability to Solve Mathematical Problems,” Int. J. Bus. Soc. Sci., vol. 6, no. 4, 2015, pp. 152-165.

[17] D. Jagals, V.D.W. Marthie, Enabling metacognitive skills for mathematics problem solving: A collective case study of metacognitive reflection and awareness, African J. Res. Math. Sci. Technol. Educ., vol. 20, no. 2, 2016, pp. 154-164.

[18] R. Fitriyah, Identifikasi Level Metakognitif Siswa MA Muhammadiyah 1 Malang dalam Memecahkan Masalah Matematika, University of Muhammadiyah Malang, 2013.

[19] S.R. Yuliati, I. Lestari, Higher-order thinking skills (HOTS) analysis of students in solving HOTS question in higher education, Perspekt. Ilmu Pendidik., vol. 32, no. 2, 2018, pp. 181-188.

[20] L.A. Mahromah, Identifikasi tingkat metakognisi siswa dalam memecahkan masalah matematika berdasarkan perbedaan skor matematika, MATHEdunesa, vol. 2, no. 1, 2013.

[21] D. Setyadi, S. Subanji, M. Muksar, Identification of students' metacognition level in solving mathematics problem about sequence, IOSR J. Res. Method Educ., vol. 6, 2016.

[22] M. V. Siagian, S. Saragih, B. Sinaga, Development of Learning Materials Oriented on Problem-Based Learning Model to Improve Students' Mathematical Problem Solving Ability and Metacognition Ability, Int. Electron. J. Math. Educ., vol. 14, no. 2, 2019, pp. 331-340.

[23] M. Trisnani, W. Winarso, Identification of Students Metacognition Levels in Problem-Solving and Mathematical Literacy, Cahaya Pendidik., vol. 5, no. 2, 2019, pp. 13-29.

[24] W. Lestari, L.D. Pratama, J. Jailani, Metacognitive Skills in Mathematics Problem Solving, J. Daya Mat., vol. 6, no. 3, 2018, pp. 286-295.

[25] N.A. Nasution, Distribution of Inheritance Against Girls: Analysis Study in Tanjung Mompang Village, Panyabungan Utara District, Mandailing Natal Regency, Indones. J. Interdiscip. Islam. Stud., vol. 3, no. 2, 2020, pp. 73-95.

[26] M.B. Miles, A.M. Huberman, J. Saldana, Qualitative data Analysis, 3rd ed. United States of America: SAGE Publications, Inc., 2014.

[27] T. Laurens, Penjenjangan Metakognisi Siswa yang Valid dan Reliabilitas, J. Pendidik. dan Pembelajaran, vol. 17, no. 2, 2010, pp. 201-211.

[28] M.T. Magiera, J.S. Zawojewski, Characterizations of Social-Based and Self-Based Contexts Associated With Students' Awareness, Evaluation, and Regulation of Their Thinking During SmallGroup Mathematical Modeling, J. Res. Math. Educ., vol. 42, no. 5, 2011, pp. 486-520.

[29] D. Purnomo, S. Bekti, Patterns Change of Awareness Process, Evaluation, and Regulation on Mathematics Student, Int. Electron. J. Math. Educ., vol. 12, no. 7, 2017, pp. 715-733.

[30] S. Jaleel, P. Premachandran, A Study on the Metacognitive Awareness of Secondary School Students, Univers. J. Educ. Res., vol. 4, no. 1, 2016, pp. $165-172$.

[31] A. Rofii, S. Sunardi, M. Irvan, Characteristics of Students' Metacognition Process At Informal Deduction Thinking Level in Geometry Problems, Int. J. Emerg. Math. Educ., vol. 2, no. 1, 2018, pp. 89-104.

[32] G. Schraw, D. Moshman, Metacognitive theories, Educ. Psychol. Rev., vol. 7, no. 4, 1995, pp. 351371.

[33] T. García, J. Boom, E.H. Kroesbergen, J. C. Núñez, C. Rodríguez, Planning, execution, and revision in mathematics problem solving: Does the order of the phases matter?, Stud. Educ. Eval., vol. 61, no. February, 2019, pp. 83-93.

[34] B. Cozza, M.J. Oreshkina, Cross-Cultural Study of Cognitive and Metacognitive Processes During Math Problem Solving, Sch. Sci. Math., vol. 113, no. 6,2013 , pp. $275-284$

[35] A. Kuzle, Patterns of metacognitive behavior during mathematics problem-solving in a dynamic geometry environment, Int. Electron. J. Math. Educ., vol. 8, no. 1, 2013, pp. 20-40.

[36] S. Saygili, Examining The Problem Solving Skills and The Strategies Used by High School Students in Solving Non-routine Problems, E-International J. Educ. Res., vol. 8, no. 2, 2017, pp. 91-114. 